\title{
A New Shrimp Genus (Crustacea: Decapoda) from the Deep Atlantic and an Unusual Cleaning Mechanism of Pelagic Decapods
}

\author{
Alexander Vereshchaka *(D), Dmitry Kulagin (D) and Anastasiia Lunina \\ Shirshov Institute of Oceanology, Russian Academy of Sciences, Nakhimovski Prospekt 36, \\ 117997 Moscow, Russia; kulagin.dima@gmail.com (D.K.); lunina@ocean.ru (A.L.) \\ * Correspondence: alv@ocean.ru
}

Citation: Vereshchaka, A.;

Kulagin, D.; Lunina, A. A New

Shrimp Genus (Crustacea: Decapoda)

from the Deep Atlantic and an

Unusual Cleaning Mechanism of

Pelagic Decapods. Diversity 2021, 13,

536. https://doi.org/10.3390/

d13110536

Academic Editor: Michael Wink

Received: 7 October 2021

Accepted: 22 October 2021

Published: 26 October 2021

Publisher's Note: MDPI stays neutral with regard to jurisdictional claims in published maps and institutional affiliations.

Copyright: (c) 2021 by the authors. Licensee MDPI, Basel, Switzerland. This article is an open access article distributed under the terms and conditions of the Creative Commons Attribution (CC BY) license (https:/ / creativecommons.org/licenses/by/ $4.0 /)$.

\begin{abstract}
The deep sea is the largest biome on Earth and hosts the majority of as yet undescribed species; description of these may trigger a new mindset about evolution and function of characters. We describe and diagnose a new genus and species Sclerodora crosnieri sp. nov. belonging to the superfamily Oplophoroidea. We examined and coded 81 characters for morphological analyses and used four gene markers for molecular analyses involving the new taxon and representatives of all other genera of Oplophoroidea. Retrieved morphological and molecular trees were similar and suggested that the new genus is a sister group to Hymenodora and both form a clade sister to the rest of Acanthephyridae. We provide an amended key to all genera of Oplophoroidea. We found an unusual chelate structure on the dactyl of the fifth pereopod, tested and confirmed a hypothesis that this structure is common for the whole family Acanthephyridae. We suggest that this derived structure is linked to an active cleaning of branchia-a function associated with chelipeds in some other carid shrimps. Convergent chelate structures are likely efficient for cleaning branchia, whichever appendage is adapted for these functions. In Oplophoridae (sister to Acanthephyridae), cleaning function is carried out by well-developed epipods.
\end{abstract}

Keywords: Caridea; phylogeny; morphology; new taxon; Oplophoroidea

\section{Introduction}

The deep sea (i.e., below $200 \mathrm{~m}$ in depth) is the largest biome on Earth; the deeppelagic domain accounts for nearly $94 \%$ of the habitable volume of the World Ocean [1], whereas only $16 \%$ of all named species on Earth are marine [2]. The deep-sea is suggested to host the majority of as yet undescribed species, which results in continuous discovery of new taxa from this environment. This process, which is usually a routine in zoology, occasionally yields taxa triggering a new mindset about evolution of characters and their functions.

In fact, while examining the deep pelagic fauna of the Central Atlantic, we found an unusual shrimp of the superfamily Oplophoroidea [3], which could not be attributed to any of the oplophoroid genera. Further sequencing of gene markers confirmed results of morphological analyses and the generic status of the new taxon. Here we examine and code 81 characters for morphological analyses and use four gene markers for molecular analyses to map the taxon on the phylogenetic tree.

Morphological examinations of the new genus resulted in a reanalysis of cleaning mechanism of the whole superfamily Oplophoroidea. Cleaning and grooming of branchia is an important function and a significant challenge for decapods and involves various mechanisms [4]. In Caridea, one of mechanism (a passive one) is linked to setobranchs and a hooked epipod unique to this group. The epipod hook of one appendage fits around the bases of the setobranch setae on the appendage posterior to it. During limb movements, when the coxae of these two limbs move apart, the setobranch setae are drawn down 
over the gill lamellae. When the coxae move toward each other, the setobranch setae are guided back to the gills through the epipod hook. When the epipod hook is displaced from the setobranch, the setae of the latter lose their location with respect to the gills [4]. An alternative mechanism (an active one) is linked to grooming chelipeds: one pair is generally used in body grooming and cleaning the gills when epipod-setobranch complexes have been lost $[5,6]$. Generally, each of these mechanisms is conservative at the genus and family level in the Caridea and the active and passive cleaning do not occur together [4].

In our specimen, neither of the described mechanisms was possible: epipods on the last two pairs of the pereopods (fourth and fifth) were absent and no gill-cleaning structures on the chelipeds were observed. Instead, the specimen has a very specialized dactyl of the fifth pereopods: short and forming a very characteristic chelate structure. We hypothesized that this character may mirror an alternative active cleaning mechanism involving the fifth pereopod, not the chelipeds as in other carids. In order to test this hypothesis, we checked structure of epipods and fifth pereopods in all other species of the superfamily Oplophoroidea, ran phylogenetic analyses, and mapped these characters on the resulting trees.

Oplophoroidea hitherto included 70 valid species within the two families, Oplophoroidea and Acanthephyridae; Oplophoridae encompass three genera (Janicella Chace, 1986, Oplophorus H. Milne Edwards, 1837, and Systellaspis Spence Bate, 1888) and are considered as a sister clade to Acanthephyridae [7], which includes Acanthephyra A. Milne-Edwards, 1881, Ephyrina Smith, 1885, Heterogenys Chace, 1986, Hymenodora G.O. Sars, 1877, Kemphyra Chace, 1986, Meningodora Smith, 1882, and Notostomus A. Milne-Edwards, 1881. Most genera are widely distributed and have been explored in numerous publications of the 19th and 20th centuries (e.g., [8]). Oplophoroidea was recently revised on the basis of both morphological and molecular analyses ([7,9-11]) and the finding of an undescribed genus and species belonging to this superfamily is surprising.

\section{Methods}

\subsection{Morphological Analysis}

We chose outgroups from Pasiphaeoidea and Bresilioidea, both representing the sister clade to Oplophoroidea ([12], Figure 1). In analysis 1 we used Pasiphaea sivado (Risso, 1816), the type species of Pasiphaea, as the outgroup. In Analysis 2, we used Alvinocaris longirostris Kikuchi and Ohta, 1995 as the outgroup. In addition to a new species, we included as the ingroups representatives of all valid species of Hymenodora (four species), and representatives of all other genera of Oplophoroidea: three genera of Oplophoridae and seven genera of Acanthephyridae (Table 1).

Table 1. Individuals used in morphological analyses. MNHN - National Museum of Natural History (Paris, France); ZMUK-National History Museum, Copenhagen, Denmark; IO RAN_Institute of Oceanology, Russian Academy of Scienses, USNM -National Museum of Natural History, Smithsonian Institution.

\begin{tabular}{cccc}
\hline Species & Coordinates & Other Information & Museum, Number \\
\hline Acanthephyra quadrispinosa & $29^{\circ} 39^{\prime} \mathrm{S}, 44^{\circ} 16^{\prime} \mathrm{E}$ & $\begin{array}{c}\text { Expedition ATIMO VATAE. SUD } \\
\text { MADAGASCAR, Sud Pointe Barrow. } \\
\text { Chaultier “Nosy Be 11”, Stn. CP 3596, } \\
986-911 \mathrm{~m} \text {. 12.05.2010. }\end{array}$ & MNHN-IU-2010-4285 \\
\hline Acanthephyra acutifrons & $14^{\circ} 43^{\prime} \mathrm{N}, 45^{\circ} 02^{\prime} \mathrm{W}$ & $\begin{array}{c}\text { “Professor Logatchev” 39 cruise St 215 } \\
\text { RT, RTAK }\end{array}$ & IO RAN 39L 215 RT №1 \\
\hline Ephyrina ombango & $\begin{array}{c}10^{\circ} 23,17^{\prime} \mathrm{N}, \\
46^{\circ} 45,34^{\prime} \mathrm{W}\end{array}$ & $\begin{array}{c}\text { DEMERABY, CP07, chalutage 4850 m. } \\
\text { 20.09.80 }\end{array}$ & MNHN-IU-2018-1579 \\
\hline Ephyrina ombango & $9^{\circ} 18^{\prime} \mathrm{S}, 11^{\circ} 10^{\prime} \mathrm{E}$ & $\begin{array}{c}\text { “Ombango", C14, St.325,midwater traul, } \\
0-725 \mathrm{~m}, 02.03 .1961,23 \mathrm{~h} 00-23 \mathrm{~h} 15\end{array}$ & MNHN-IU-2014-11098 \\
\hline
\end{tabular}


Table 1. Cont.

\begin{tabular}{|c|c|c|c|}
\hline Species & Coordinates & Other Information & Museum, Number \\
\hline Heterogenis microphtalma & No data & $\begin{array}{l}\text { Collection de S.A.S.le Prince de Monaco, } \\
\text { Station 7/3. №12h, 16-19.8.96. Chal } \\
4360 \mathrm{~m}\end{array}$ & MNHN-IU-2018-1578 \\
\hline Hymenodora acanthitelsonis & $\begin{array}{c}45^{\circ} 18^{\prime} \mathrm{N} \\
125^{\circ} 43^{\prime} \mathrm{W}-45^{\circ} 17^{\prime} \mathrm{N} \\
125^{\circ} 49^{\prime} \mathrm{W}\end{array}$ & $\begin{array}{c}\text { Pacific Ocean, Unated States, Oregon, W } \\
\text { of Pacific City. Yaqina BMT.189, } \\
\text { 18.03.1970. }\end{array}$ & USNM 137500 \\
\hline Hymenodora glacialis & $02^{\circ} 03^{\prime} \mathrm{S}, 118^{\circ} 45^{\prime} \mathrm{E}$ & $\begin{array}{l}\text { Indonesie, CORINDON -Makassar. St } \\
\text { CH286, 1710-1730 m }\end{array}$ & Na 10655 \\
\hline Hymenodora glacialis & $73^{\circ} 28^{\prime} \mathrm{N}, 10^{\circ} 07^{\prime} \mathrm{W}$ & $\begin{array}{c}\text { Mer de Norvege, Campagne NORBI, } \\
\text { N.O. "Jean Charcot", Stn CP16, } 2937 \text { m, } \\
07.08 .1975\end{array}$ & MNHN-IU-2008-16833 \\
\hline Hymenodora gracilis & $37^{\circ} 39^{\prime} \mathrm{S}, 77^{\circ} 26^{\prime} \mathrm{E}$ & $\begin{array}{l}\text { Ile Amsterdam, Campagne Jasus (MD } \\
\text { 50), N.O. “Marion Dufresne”, Stn CP193, } \\
\text { 2800-3075 m. 27.06.1986 }\end{array}$ & MNHN-IU-2008-16839 \\
\hline Hymenodora frontalis & $15^{\circ} \mathrm{N}, 45^{\circ} \mathrm{W}$ & $\begin{array}{l}\text { ROV “Vityaz", } 59 \text { th cruise, st. 7497, № } \\
\text { 271. 18.06.1976, 1500-2500 m }\end{array}$ & \\
\hline Janicella spinicauda & $1^{\circ} 28^{\prime} \mathrm{S}, 48^{\circ} 06^{\prime} \mathrm{E}$ & $\begin{array}{l}\text { ROV “Vityaz”, 17th cruise, St. } \\
\text { 2604,13.11.88, 670-690 m }\end{array}$ & ZMUK \\
\hline Janicella spinicauda & $8^{\circ} 44^{\prime} \mathrm{S}, 43^{\circ} 54^{\prime} \mathrm{E}$ & $\begin{array}{l}\text { Dana Expedition, St. 3939-1, 23.12.1929, } \\
\qquad 500 \text { meter wire }\end{array}$ & ZMUK \\
\hline Kemphyra corallina & $37^{\circ} 54^{\prime} \mathrm{S}, 77^{\circ} 22^{\prime} \mathrm{E}$ & $\begin{array}{l}\text { Iles St Paul et Amsterdam, “Marion } \\
\text { Dufresne" Cne MD Jasus Stn CP } 56 . \\
2280-2310 \text { m. 14.07.1986. 20h02-22h31 }\end{array}$ & MNHN-IU-2018-1581 \\
\hline Kemphyra corallina & $33^{\circ} 59^{\prime} \mathrm{S}, 43^{\circ} 55^{\prime} \mathrm{E}$ & $\begin{array}{l}\text { Indian Ocean: Walters shoal, Plaine Sud. } \\
\text { N.O. “Marion Dufresne”, Campagne } \\
\text { MD208(Walters Shoal). Stn CP49156 } \\
\text { 1865-2058 m, 12.05.2017 }\end{array}$ & MNHN-IU-2016-9402 \\
\hline Meningodora longiscula & $9^{\circ} 55^{\prime} \mathrm{N}, 142^{\circ} 00^{\prime} \mathrm{E}$ & $\begin{array}{c}\text { Nouvelle-Caledonie, Campagne Caride V. } \\
\text { Stn 15, } 1000 \text { m. } 12.09 .1969\end{array}$ & MNHN-IU-2011-5635 \\
\hline Notostomus elegans & & 37 cruise RV Logatchev, St 156 TS & IO RAN \\
\hline Oplophorus gracilirostris & $25^{\circ} 11^{\prime} \mathrm{N}, 122^{\circ} 35^{\prime} \mathrm{E}$ & Dana Expedition, St. 3722-3, $300 \mathrm{~m}$ wire & ZMUK \\
\hline Oplophorus gracilirostris & $20^{\circ} 08^{\prime} \mathrm{N}, 82^{\circ} 59^{\prime} \mathrm{W}$ & Dana Expedition, St. 1218, 800 m wire & ZMUK \\
\hline Oplophorus gracilirostris & $12^{\circ} 30^{\prime} \mathrm{S}, 48^{\circ} 16^{\prime} \mathrm{E}$ & $\begin{array}{l}\text { ROV “Vityaz", 17th cruise, St. 2597, } \\
\text { 12.11.88, 360-555 m wire. }\end{array}$ & ZMUK \\
\hline Oplophorus gracilirostris & $22^{\circ} 06^{\prime} \mathrm{N}, 84^{\circ} 58^{\prime} \mathrm{W}$ & Dana Expedition, St. $1223,500 \mathrm{~m}$ wire & ZMUK \\
\hline Pasiphaea sivado & $35^{\circ} 47^{\prime} \mathrm{N}, 05^{\circ} 17^{\prime} \mathrm{W}$ & $\begin{array}{c}\text { Detroit de Gibraltar, N.O. “Cryos”, } \\
\text { BALGIM, St. CP150, 280-300 m, } \\
\text { 18.06.1984 }\end{array}$ & MNHN-IU-2018-1611 \\
\hline Sclerodora crosnieri sp.nov. & $16^{\circ} \mathrm{N}, 46^{\circ} \mathrm{W}$ & $\begin{array}{l}\text { 39th Cruise of R/V “Professor } \\
\text { Logatchev", March } 2018\end{array}$ & ZMUK \\
\hline Systellaspis pellucida & $12^{\circ} 30^{\prime} \mathrm{S}, 48^{\circ} 16^{\prime} \mathrm{E}$ & $\begin{array}{l}\text { Indian Ocean. North end of Madagascar. } \\
\text { ROV “Vityaz", 17th cruise, St. 2597, } \\
\text { 360-555 m }\end{array}$ & IO RAN \\
\hline Systellaspis pellucida & $25^{\circ} 11^{\prime} \mathrm{N}, 122^{\circ} 35^{\prime} \mathrm{E}$ & $\begin{array}{l}\text { North Western Pacific Ocean. S.E. and E. } \\
\text { of Formosa. Dana Expedition 3722(2) } \\
\text { 29.05.1929, } 600 \mathrm{mw}\end{array}$ & ZMUK \\
\hline Systellaspis pellucida & $25^{\circ} 11^{\prime} \mathrm{N}, 122^{\circ} 35^{\prime} \mathrm{E}$ & $\begin{array}{l}\text { North Western Pacific Ocean. S.E. and E. } \\
\text { of Formosa. Dana Expedition 3722(1) } \\
\text { 29.05.1929, } 1000 \mathrm{mw}\end{array}$ & ZMUK \\
\hline
\end{tabular}



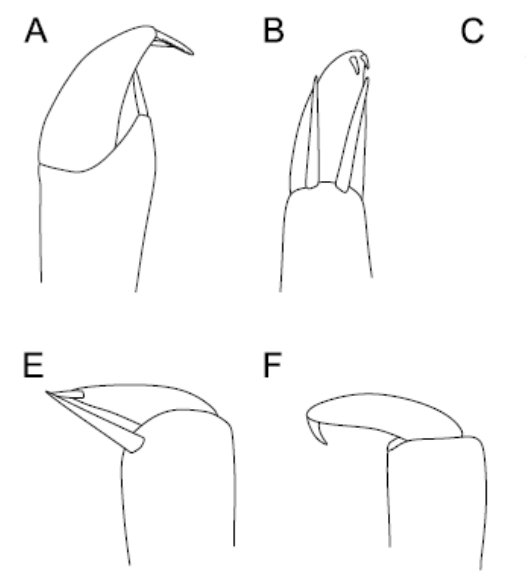

$\mathrm{F}$
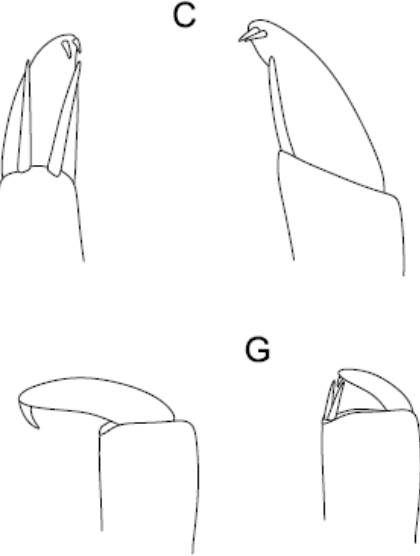

D

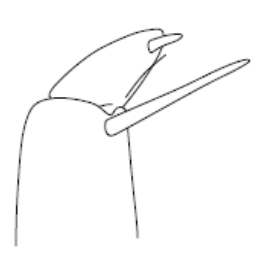

G

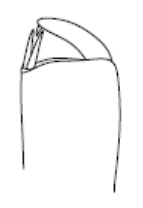

$\mathrm{H}$

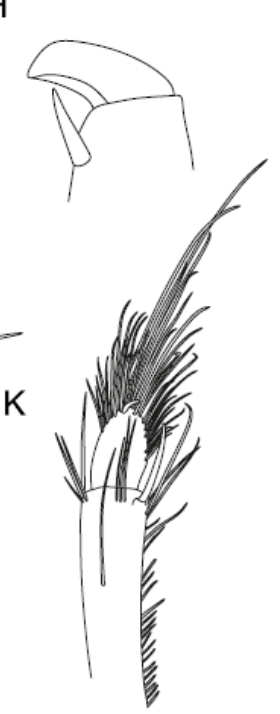

Figure 1. Terminal part of the fifth pereopod in Oplophoroidea (schematic, most non-robust setae removed): (A)—Sclerodora crosnieri, sp. nov., (B)—Hymenodora frontalis, side view, (C)—Hymenodora frontalis, inner view, (D)—Acanthephyra acutifrons, (E) - Notostomus elegans, (F) - Kemphyra corallina, (G)_Meningodora longisulca, (H)_Heterogenys microphthalma, (I)—Systellaspis debilis, (J)—Oplophorus gracilirostris, (K)_Janicella spinicauda.

For each included taxon we identified and encoded 81 morphological characters (not weighted, Supporting Information, File S1. The dataset (File S2) was handled and analyzed using a combination of programs using maximum parsimony settings: WINCLADA/NONA and TNT $[13,14]$. Trees were generated in TNT with 30,000 trees in memory, under the 'implicit enumeration' algorithm. Relative stability of clades was assessed by standard bootstrapping (sample with replacement) with 10,000 pseudoreplicates and by Bremer support (algorithm TBR, saving up to 10,000 trees up to 8 steps longer). In all analyses, clades were considered robust if they had synchronously Bremer support $\geq 3$ and bootstrap support $\geq 70$.

\subsection{Molecular Analyses}

In order to resolve the phylogenetic position of the new species within the superfamily Oplophoroidea, we selected two mitochondrial (COI, 16S) and two nuclear genes (18S, H3) owing to their phylogenetic utility and different inheritance patterns. Outgroups and ingroups were the same as in the morphological analysis. NCBI GenBank accession numbers of sequences taken for phylogenetic analysis are listed in Table 2. 
Table 2. Details of the analyzed species and sequences used in the study. Newly retrieved sequences are highlighted in bold; 'N'-missing data.

\begin{tabular}{|c|c|c|c|c|c|}
\hline \multirow{2}{*}{ Taxon } & \multicolumn{4}{|c|}{ GenBank Accession Numbers } & \multirow[t]{2}{*}{ Source } \\
\hline & COI & $16 S$ & $18 S$ & H3 & \\
\hline \multicolumn{6}{|l|}{ Outgroup taxa } \\
\hline \multicolumn{6}{|l|}{ Pasiphaeoidea Dana, 1852} \\
\hline \multicolumn{6}{|l|}{ Pasiphaeidae Dana, 1852} \\
\hline Pasiphaea sivado (Risso, 1816) & KP759487 & KP725629 & KP725826 & MF279416 & $\begin{array}{l}\text { Aznar-Cormano } \\
\text { et al., 2015; Liao } \\
\text { et al., } 2017\end{array}$ \\
\hline \multicolumn{6}{|l|}{ Bresilioidea Calman, 1896} \\
\hline \multicolumn{6}{|l|}{ Alvinocarididae Christoffersen, 1986} \\
\hline $\begin{array}{c}\text { Alvinocaris longirostris Kikuchi \& } \\
\text { Ohta, } 1995\end{array}$ & KP215329 & KP215285 & KP215300 & KP215342 & $\begin{array}{l}\text { Aznar-Cormano } \\
\text { et al., } 2015\end{array}$ \\
\hline \multicolumn{6}{|l|}{ Ingroup taxa } \\
\hline \multicolumn{6}{|l|}{ Oplophoroidea Dana, 1852} \\
\hline \multicolumn{6}{|l|}{ Oplophoridae Dana, 1852} \\
\hline $\begin{array}{l}\text { Janicella spinicauda (A. } \\
\text { Milne-Edwards, 1883) }\end{array}$ & MH572546 & КР075932 & MH100869 & MH107256 & $\begin{array}{c}\text { Wilkins and } \\
\text { Bracken-Grissom, } \\
2020 \text { (GenBank); } \\
\text { Wong et al., 2015; } \\
\text { Lunina et al., } 2019\end{array}$ \\
\hline $\begin{array}{l}\text { Oplophorus gracilirostris A. } \\
\text { Milne-Edwards, } 1881\end{array}$ & KР076150 & КР075920 & КР075847 & КР076072 & Wong et al., 2015 \\
\hline Systellaspis pellucida (Filhol, 1884) & JQ306184 & КР075925 & JF346250 & KР076077 & $\begin{array}{c}\text { Matzen da Silva } \\
\text { et al., 2011; Wong } \\
\text { et al., 2015; Li et al., } \\
2011\end{array}$ \\
\hline \multicolumn{6}{|l|}{ Acanthephyridae Spence Bate, 1888} \\
\hline $\begin{array}{c}\text { Acanthephyra quadrispinosa } \\
\text { Kemp, } 1939\end{array}$ & KP759363 & KP725479 & KP725677 & KP726051 & $\begin{array}{l}\text { Aznar-Cormano } \\
\text { et al., } 2015\end{array}$ \\
\hline $\begin{array}{c}\text { Ephyrina ombango Crosnier \& } \\
\text { Forest, } 1973\end{array}$ & MW043004 & MW043448 & MW043463 & MW052289 & Lunina et al., 2020 \\
\hline $\begin{array}{l}\text { Heterogenys microphthalma } \\
\text { (Smith, 1885) }\end{array}$ & КР076183 & КР075898 & KP075787 & КР076124 & Wong et al., 2015 \\
\hline $\begin{array}{c}\text { Kemphyra corallina } \\
\text { (A.Milne-Edwards, 1883) }\end{array}$ & MW043006 & MW043450 & MW043465 & MW052291 & Lunina et al., 2020 \\
\hline Meningodora longisulca Kikuchi, 1985 & MW043007 & MW043451 & MW043466 & MW052292 & Lunina et al., 2020 \\
\hline $\begin{array}{l}\text { Notostomus elegans A. } \\
\text { Milne-Edwards, } 1881\end{array}$ & MW043011 & MW043455 & MW043470 & MW052296 & Lunina et al., 2020 \\
\hline Hymenodora frontalis Rathbun, 1902 & DQ882080 & $\mathrm{N}$ & $\mathrm{N}$ & $\mathrm{N}$ & Costa et al., 2007 \\
\hline Hymenodora glacialis (Buchholz, 1874) & FJ602519 & GQ131896 & GQ131915 & $\mathrm{N}$ & $\begin{array}{l}\text { Bucklin et al., 2010; } \\
\text { Chan et al., } 2010\end{array}$ \\
\hline Hymenodora gracilis Smith, 1886 & MH572613 & MH542891 & КР075827 & КР076134 & $\begin{array}{c}\text { Wilkins and } \\
\text { Bracken-Grissom, } \\
2020 \text { (GenBank); } \\
\text { Wong et al., } 2015\end{array}$ \\
\hline Sclerodora crosnieri gen. nov., sp. nov. & OK382996 & OK382953 & OK382952 & OK424597 & This study \\
\hline
\end{tabular}


Total genomic DNA was extracted from the fifth pleopod using the Qiagen DNeasy ${ }^{\circledR}$ Blood and Tissue Kit in accordance with the manufacturer's protocol. Polymerase chain reaction (PCR) amplification of the COI gene was performed with the primers COI-acantfor2a (5'-GGDGTNGGNACDGGNTGRAC-3') and/COH6 [15]. We have designed a new internal primer within the barcoding region, since all attempts at amplification with LCO 1490 [16] or COL6 [17] primers were unsuccessful. The length of the resulting fragment was $397 \mathrm{bp}$. The mitochondrial large subunit 16S rRNA was amplified by 16L2/16H3 primers ( 550 bps, $[18,19])$, the nuclear small subunit $18 \mathrm{~S}$ rRNA was amplified by A/L, $\mathrm{C} / \mathrm{Y}, \mathrm{O} / \mathrm{B}$ primers ( 1800 bps, [20]), and $\mathrm{H} 3$ gene fragment was amplified by H3A/H3B primers ( 330 bps, [21]). A pre-made PCR mix (ScreenMix-HS) from Evrogene ${ }^{\mathrm{TM}}(1 \times$ ScreenMix-HS, $0.4 \mu \mathrm{M}$ of each primer, $1-1.5 \mu \mathrm{L}$ of DNA template, and completed with milliQ $\mathrm{H}_{2} \mathrm{O}$ to make up a total volume of $20 \mu \mathrm{L}$ ) was used for the amplification. The thermal profile used an initial denaturation for $3 \mathrm{~min}$ at $95^{\circ} \mathrm{C}$ followed by $35-40$ cycles of $20 \mathrm{~s}$ at $94^{\circ} \mathrm{C}, 30 \mathrm{~s}$ at $47-56^{\circ} \mathrm{C}$ depending on primer pair, $1 \mathrm{~min}$ at $72^{\circ} \mathrm{C}$ and a final extension of $7 \mathrm{~min}$ at $72{ }^{\circ} \mathrm{C}$. PCR products were purified by ethanol precipitation and sequenced in both directions using BigDye Terminator v3.1 (Applied Biosystems, Foster City, CA, USA). Each sequencing reaction mixture, including $0.5 \mu \mathrm{L}$ of BigDye Terminator v3.1, $0.8 \mu \mathrm{L}$ of $1 \mu \mathrm{M}$ primer, and 1-2 $\mu \mathrm{L}$ of purified PCR template, was run for 30 cycles of $96^{\circ} \mathrm{C}(10 \mathrm{~s})$, $50{ }^{\circ} \mathrm{C}(5 \mathrm{~s})$, and $60^{\circ} \mathrm{C}(4 \mathrm{~min})$. Sequences were purified by ethanol precipitation to remove unincorporated primers and dyes. Products were re-suspended in $14 \mu \mathrm{L}$ formamide and electrophoresed in ABI Prism-3500 sequencer (Applied Biosystems) at the joint usage center 'Methods of molecular diagnostics' of the IEE RAS. The nucleotide sequences were cleaned and assembled using CodonCode Aligner version 7.1.1. Protein-coding sequences (COI, $\mathrm{H} 3$ ) were checked for indels and stop codons to prevent the inclusion of pseudogenes. All sequences were then compared to genes reported in GenBank using BLAST (National Center for Biotechnology Information, NCBI) to check for potential contamination.

For each gene-fragment, the sequences were aligned using MUSCLE [22] implemented in MEGA version X [23], and the alignment accuracy was adjusted by eye. Missing data were designated with a "?" for any incomplete sequences. All obtained sequences were submitted to the NCBI GenBank database (Table 2).

In order to assess phylogenetic relationships between species, we run Bayesian Inference (BI) and Maximum likelihood (ML) analyses. We ran ML analysis in RAxML GUI v2.0 [24,25] applying the GTR + G model. Bootstrap resampling with 1000 replicates was made using the thorough bootstrap procedure to assign support to branches in the ML tree. Trees were generated for each individual gene dataset and examined for conflicting topologies. Final ML tree was generated using the partitioned by gene and codone dataset of all concatenated genes.

The BI analysis was conducted in MrBayes v3.2.6 [26] for the concatenated dataset of all genes. The combined dataset was partitioned and analyzed using models selected by PartitionFinder2 [27]. AICc metric implemented in PartitionFinder2 was used to obtain the optimal partitioning scheme. Two independent runs, each consisting of four chains, were executed for this analysis. A total of 10,000,000 generations were performed for the combined dataset, with sampling every 1000 generations, and the first $25 \%$ trees (i.e., 2500 trees for combined dataset) were discarded as "burn-in". A 1\% average standard deviation of split frequencies was reached after about 0.75 million generations.

We considered the clades statistically supported if they had a synchronous support of posterior probabilities $\geq 0.9$ on the BI tree and bootstrap value $\geq 70 \%$ on the ML tree.

To quantify COI genetic distances between species/genera of Oplophoroidea, we used the Kimura 2-parameter model [28] implemented in MEGA X.

\section{Results}

3.1. Morphological Analyses and Supporting Synapomorphies

Examination of epipods and fifth pereopods in all species of Oplophoroidea revealed a great conformity between both characters: 
Family Acanthephyridae, all species: epipods on the fourth pereopods absent; dactyli of the fifth pereopods short, greatly modified in a chelate structure (Figure 1A-H).

Family Oplophoridae, all species: epipods of the fourth pereopod well-developed with a prominent hook serving for cleaning of posterior branchia; dactyli of the fifth pereopods long and not greatly specialized (Figure $1 \mathrm{I}-\mathrm{K}$ ).

Phylogenetic Analysis 1 with Pasiphaea sivado as outgroup retrieved a single most parsimonious (MP) tree (Figure 2A, Files S3 and S4) with a score of $101(\mathrm{Ci}=80, \mathrm{Ri}=84)$. The tree showed three major clades: Oplophoridae, Hymenodora + Sclerodora, and the rest of Acanthephyridae. Oplophoridae was sister group to Acanthephyridae, and Hymenodora + Sclerodora was sister group to the rest of Acanthephyridae. Hymenodora was sister group to Sclerodora.

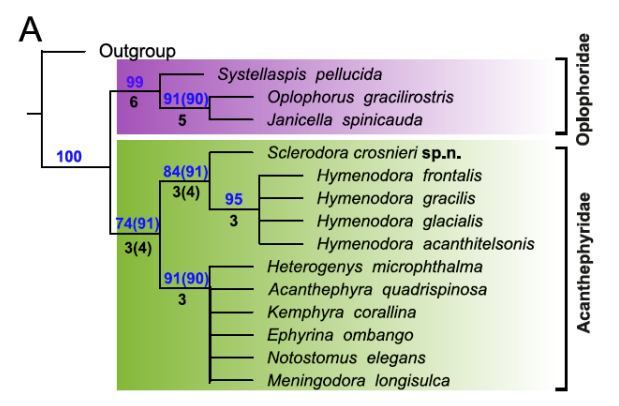

B

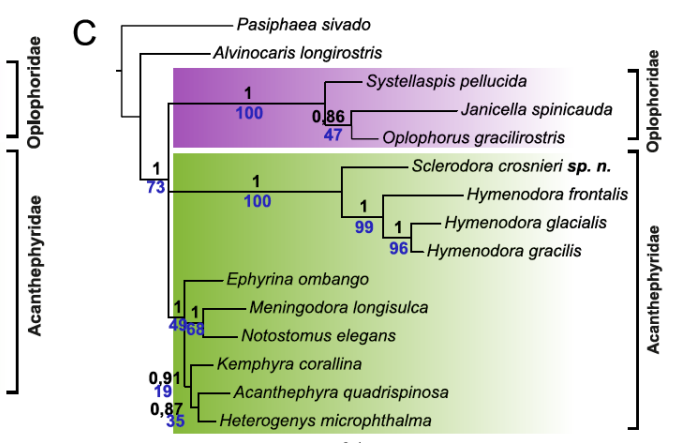

$\underline{0.1}$

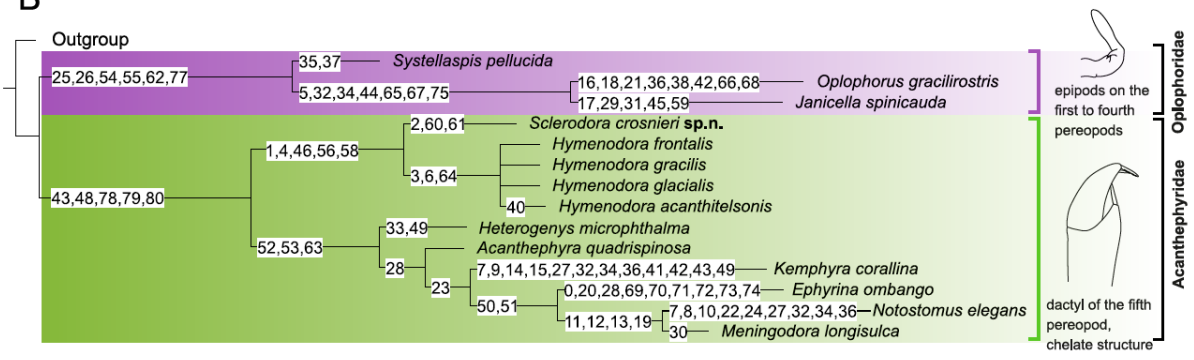

Figure 2. Phylogenetic trees with Pasiphaea sivado and Alvinocaris longirostris as outgroups. (A) morphological MP tree; only clades supported by both Bremer values (black, below branches) and bootstrap values (blue, above branches) are shown; if support values in analyses differed, values retrieved in Analysis 2 are given in parentheses. (B)—synapomorphies, above branches, see coding in File S1. (C) - molecular BI and ML tree, only supported clades are shown. The horizontal scale bar marks the number of expected substitutions per site. Statistical support indicated as Bayesian posterior probabilities (black, above branches) and ML bootstrap with 1000 replicates (blue, below branches).

Analysis 2 with Alvinocaris longirostris as outgroup also retrieved a single MP tree (Figure 2A, File S3) with a score of $100(\mathrm{Ci}=81, \mathrm{Ri}=85)$. Tree topology was the same as in Analysis 1.

The clade Hymenodora + Sclerodora was supported by five synapomorphies (Figure 2B, File S5): the presence of dorsal subuliform teeth (1) and the loss of subtriangular teeth (4) on the rostrum; a left mandible with the molar process compressed and sub-bilinear (46), a second maxilla with the proximal endite elongate, without submarginal papilla and lamina (56), and a first maxilliped with the endopod two-segmented, greatly overreaching endites (58). Within this clade, Sclerodora was supported by the presence of dorsal subuliform teeth both on the rostrum and carapace extending from the dorsal ridge (2), a second maxilliped with the terminal segment subtriangular and attached transversely (60) and bearing robust terminal setae (61). Hymenodora was supported by the presence of dorsal subuliform teeth only on the rostrum (3), a reticulum of carinae on membranous carapace (6), and a second maxilliped with the subovoid terminal segment attached diagonally (64). 


\subsection{Molecular Analyses}

A total of 15 species representing all genera of the superfamily Oplophoroidea and two outgroup species were put in the data matrix. In addition, all species of Hymenodora deposited in GenBank (three out of four) were also added to the data matrix. Prior to the analyses, all sequences from GenBank were checked for contamination or possible misidentification using BLAST search and preliminary phylogenetic reconstruction with each gene separately. ML trees generated for each individual gene dataset revealed no conflicting topologies between genes, at least in branching with bootstrap values $\geq 60 \%$ (File S6). The concatenated four-marker dataset comprised 3321 bp. Results from PartitionFinder2 recommended a 7-partition scheme by gene and codon $(\mathrm{H} 3, \mathrm{COI})$, which was used in the final analyses (File S7).

Molecular analyses (Figure 2C, File S8) showed that the new species was a sister group to Hymenodora, and both formed a common robust clade. The rest of Acanthephyridae and Oplophoridae also formed robust clades; deeper nodes within Oplophoroidea remained unresolved.

Genetic K2P distances between the new species and three Hymenodora species ranged from $31.9 \%$ to $32.9 \%$ in COI gene (File S9). These values significantly exceeded K2P distances between all Hymenodora species (9.4-27.0\%) as well as K2P distances between representatives of six genera of Acanthephyridae (17.9-28.4\%) and three genera of Oplophoridae $(23.3-28.9 \%)$.

\section{Discussion}

\subsection{Taxonomic Implication}

Results of morphological and molecular analyses were very similar and suggested the same position of Sclerodora on the phylogenetic tree. This taxon was sister to Hymenodora, and, along with Hymenodora, formed a robust clade sister to the rest of the Acanthephyridae. Calculations of genetic K2P distances suggested a generic status of the new taxon: Sclerodora was more distant from the sister Hymenodora than any pair of genera within Acanthephyridae or Oplophoridae from each other. In addition to a significant genetic distance, Sclerodora was supported by remarkable synapomorphies linked to the carapace (the presence of dorsal subuliform teeth extending from the dorsal ridge) and mouthparts (shape and articulation of the terminal segment of the second maxilliped, unique in the superfamily Oplophoroidea). Both molecular and morphological evidences suggest the generic status of Sclerodora and its position within the clade Hymenodora + Sclerodora and within the major clade Acanthephyridae.

In order to encapsulate results of morphological and molecular analyses in the phylogenetic classification, we here erect and diagnose the new genus and provide an amended key to all genera of Oplophoroidea.

\subsubsection{Sclerodora gen. nov.}

Emended diagnosis: Integument robust; rostrum overreaching eye cornea, armed with subuliform dorsal teeth, no ventral teeth; carapace with dorsal ridge armed with subuliform teeth in anterior part; antennal angle rounded, branchiostegal spine rudimentary, no hepatic spine, no uninterrupted lateral carina extending from near orbit to near posterior margin, hepatic and branchiostegal carinae weak; abdomen with all somites dorsally rounded and lacking teeth; 6th somite longer than 5th. Eyes with cornea narrower than eyestalk; antennal scale without lateral teeth; mandibles dissimilar, molar process with transverse distal surface triangular on right member of pair and compressed and sub-bilinear on left member, incisor process toothed along entire opposable margin; 1st maxilla with endopod bearing distal prominence with a single robust seta; 2 nd maxilla with proximal endite elongate, lacking papilla and submarginal lamina; 1st maxilliped with two-segmented endopod greatly overreaching endites; 2nd maxilliped with distal segment subtriangular, attached transversely to preceding segment and bearing terminal robust setae; 3 rd maxilliped and 
1st pereopod with exopods not unusually broad or rigid; pereopods with neither ischium nor merus broadly compressed, fourth pair without epipod.

Species included: Sclerodora crosnieri sp. nov.

Type species: Sclerodora crosnieri sp. nov. (type by monotypy).

Etymology: From Greek ' $\sigma \kappa \lambda \eta \rho \sigma^{\prime}$ ', firm, hard, and ' $\delta \rho \rho \alpha$ ', integument; a reference to the integument of the new species, which is firmer than that in the sister genus Hymenodora.

Remarks: Sclerodora is similar to Hymenodora and both differ from other Oplophoroidea in the replacement of usual subtriangular teeth on the rostrum with subuliform structures spaced from each other; in having an unusual molar process (compressed and sub-bilinear) on the left mandible; in a unique elongate proximal endite of the second maxilla lacking submarginal papilla and lamina; in a two-segmented endopod greatly overreaching endites of the first maxilliped. At the same time, Sclerodora differs from Hymenodora in a presence of the dorsal subuliform teeth extending from the common carina both on the rostrum and the carapace. Such a character of Sclerodora as a subtriangular terminal segment of the second maxilliped, attached transversely and bearing robust terminal setae, is unique and not found in other Oplophoroidea.

\subsubsection{Sclerodora crosnieri sp. nov.}

Material: Holotype, female, $26 \mathrm{~mm}$ carapace length, $80 \mathrm{~mm}$ total length (telson broken); 39th Cruise of R/V "Professor Logachev"; 2018, March 2; $15^{\circ} \mathrm{N}, 45^{\circ} \mathrm{W}$; Isaacs-Kidd midwater trawl, oblique tow 0-2500 m; kept in the Natural History Museum, Copenhagen University, Denmark.

Description: Carapace smooth, 1.73 times as long as high, suprabranchial and hepatic ridges prominent (Figure 3A); dorsal carina with eight small irregular teeth in $1 / 4$ anterior part; rostrum with four dorsal teeth (Figure 3B). Abdomen with sixth somite twice as long as fifth; telson (broken) with dorsolateral spines (Figure 3C).

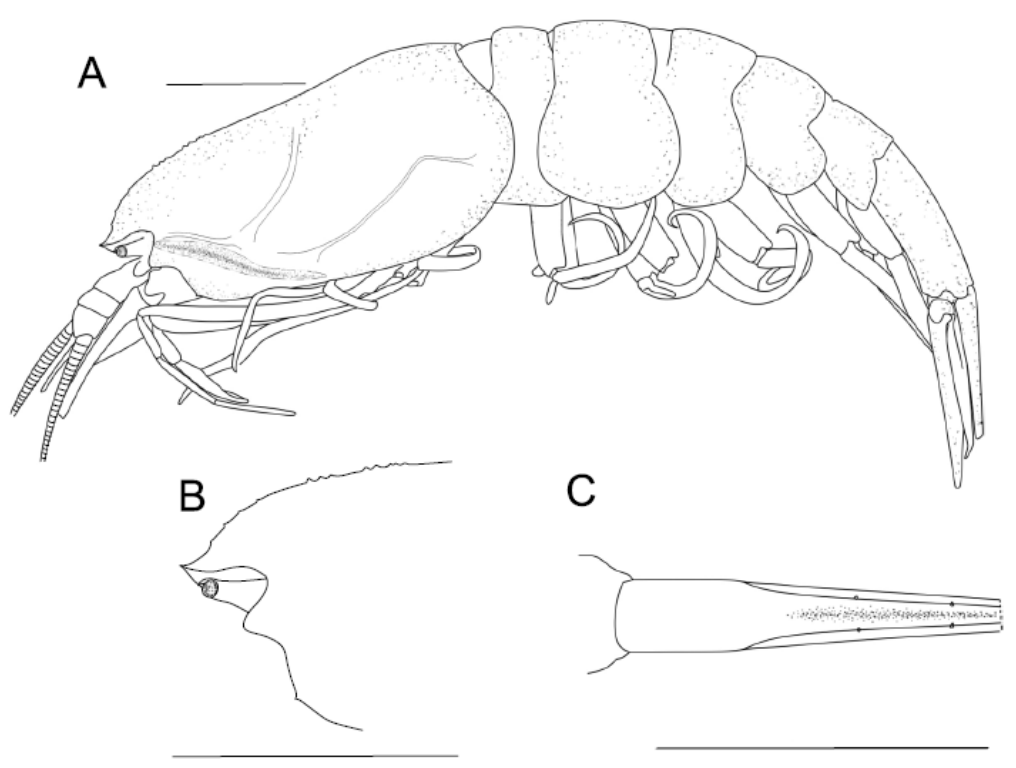

Figure 3. Body of Sclerodora crosnieri sp. nov., holotype: (A)—general view. (B)—anterior part of carapace, lateral view. (C) — telson, dorsal view. All scales: $10 \mathrm{~mm}$.

Mandible (Figure 4A) with 2-segmented palp; first maxilla with distal endite bearing two rows of robust setae (Figure $4 \mathrm{~B}$ ); second maxilla with two distal endites subequal (Figure 4C); first maxilliped with distal segment of endopod nearly twice as long as basal segment (Figure 4D); second maxilliped with distal segment bearing five terminal stout setae (Figure 4E); third maxilliped with well-developed hook-bearing epipod, distal segment densely covered with setae over entire margin (Figure 4F). First pereopod with carpus bearing distal tooth, propodus densely covered with setae over flexor margin, bearing 
large terminal and tiny subterminal spines, inner margins of chela rifled (Figure 5A-C); second pereopod with propodus bearing large terminal and tiny subterminal spines, inner margins of chela rifled (Figure 5D-F); third pereopod with ischium armed with three spines and dactyl bearing seven robust setae on flexor margin (Figure 5G); fourth pereopod with ischium armed with a single spine and dactyl bearing seven robust setae on flexor margin (Figure $5 \mathrm{H}$ ); fifth pereopod with propodus covered with rifled setae over flexor margin and a single terminal robust seta in the chelate structure, dactyl curved and bearing two terminal robust setae (Figure 5I-J).

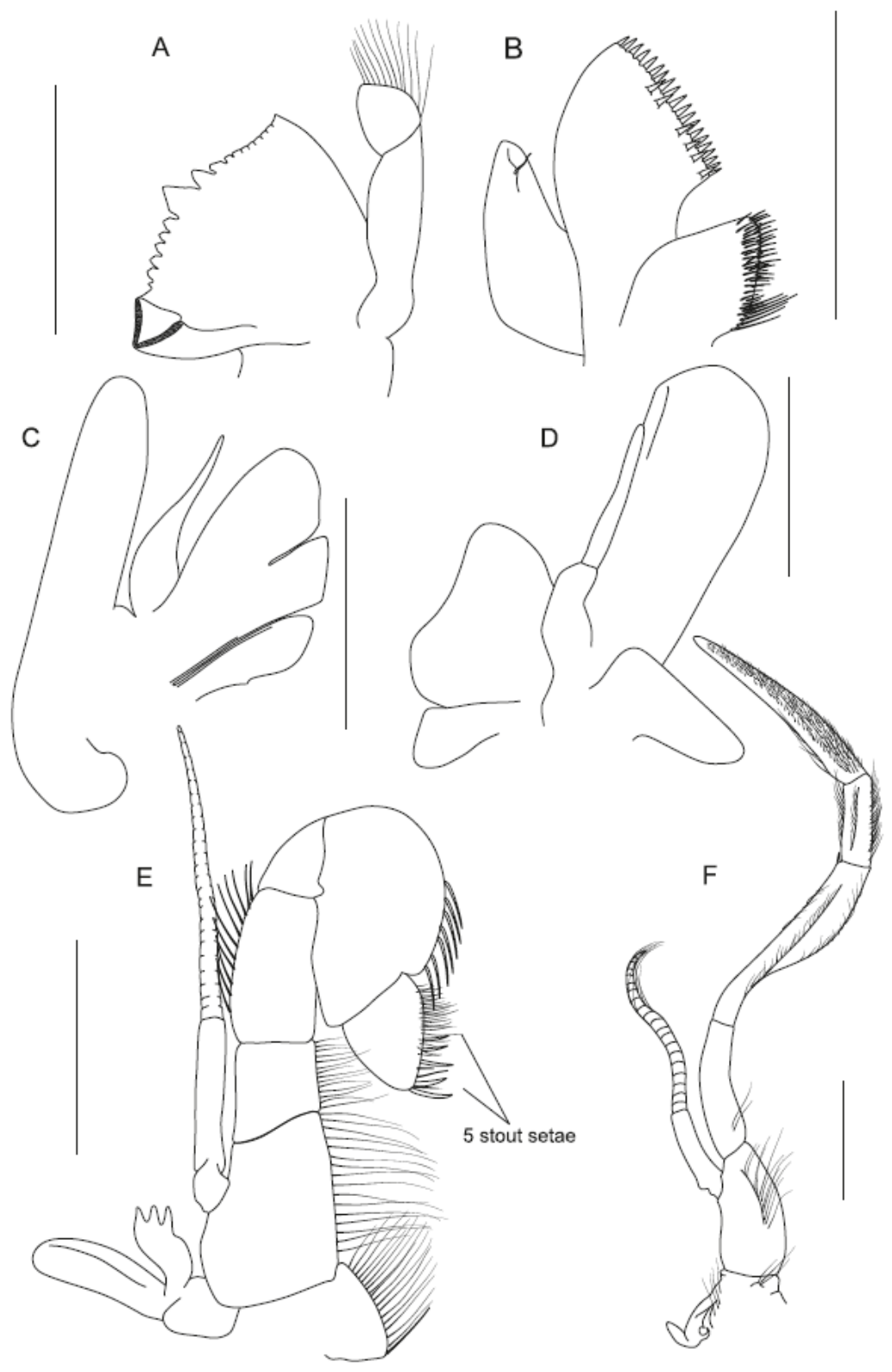

Figure 4. Mouthparts of Sclerodora crosnieri sp. nov., holotype, right parts: (A)—mandible. (B)—first maxilla, inner view. (C)—second maxilla, setae removed. (D)—first maxilliped, setae removed. (E)—second maxilliped. (F)—third maxilliped. All scales: $3 \mathrm{~mm}$. 


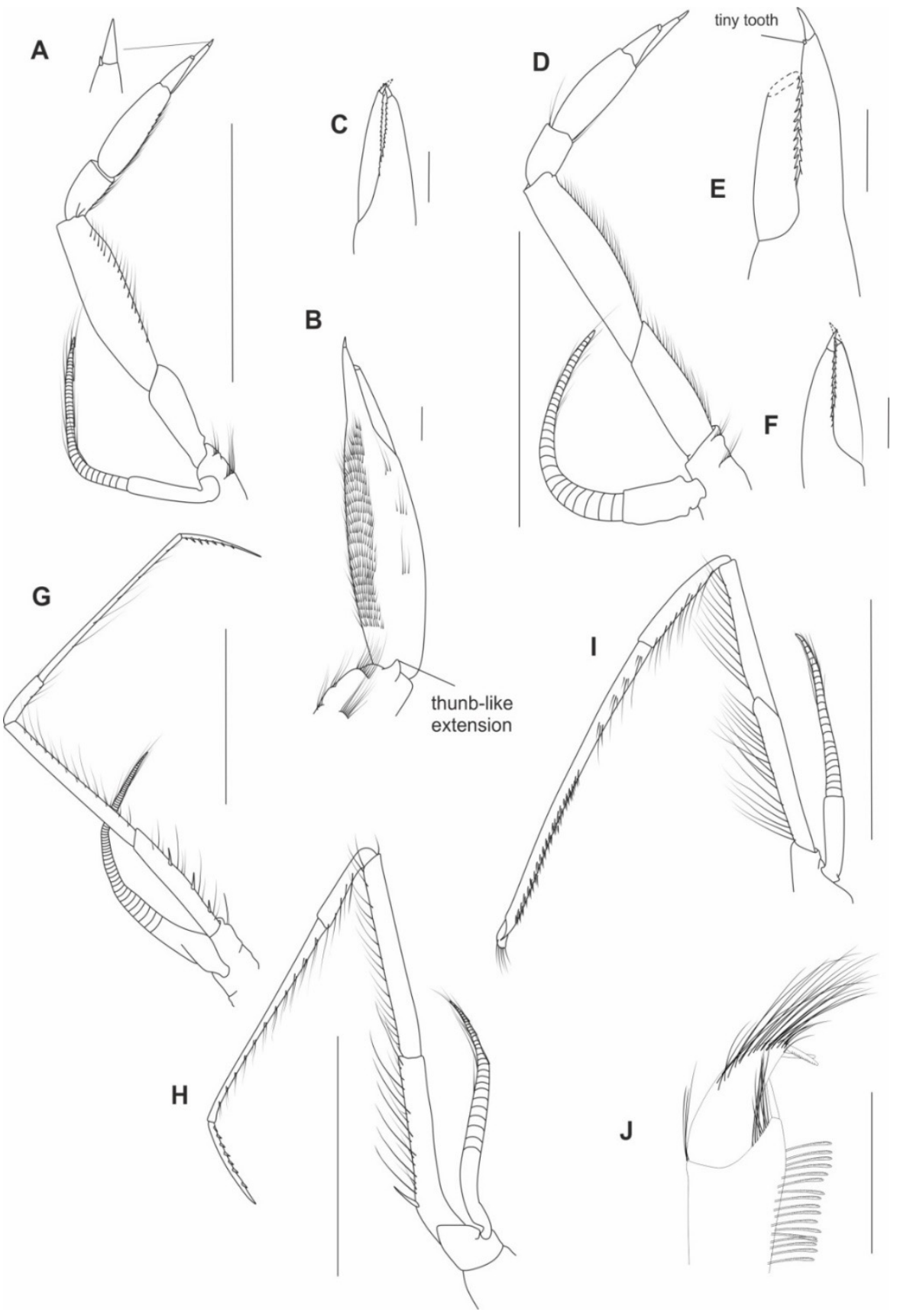

Figure 5. Pereopods of Sclerodora crosnieri sp. nov., holotype: (A)—right first pereopod. (B)—right first chela, inner view. (C) - left first chela. (D)—right second pereopod. (E)—right second chela. (F-left second chela. (G) —right third pereopod. (H)—left fourth pereopod. (I)—right fifth pereopod. (J) - terminal part of right fifth pereopod. All scales for entire pereopods: $10 \mathrm{~mm}$, all scales for their tips: $1 \mathrm{~mm}$.

Etymology: named after the late Alain Crosnier, prominent carcinologist greatly contributed to taxonomy of decapods and, in particular, oplophoroid shrimps. 


\subsubsection{Key to Genera of Oplophoroidea}

1. Sixth abdominal somite with distinct dorsal carina $\ldots \ldots \ldots \ldots \ldots \ldots \ldots \ldots \ldots$

- Sixth abdominal somite dorsally smooth $\ldots \ldots \ldots \ldots \ldots \ldots \ldots \ldots \ldots \ldots \ldots \ldots \ldots$

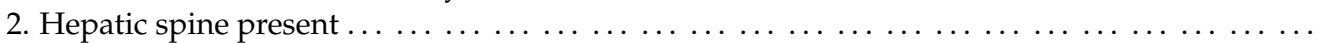

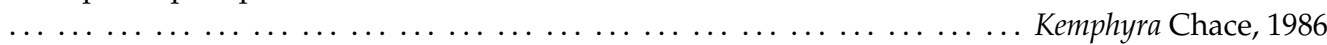

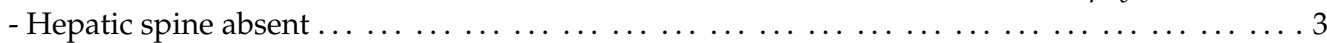

3. Third abdominal somite with long dorsal tooth overreaching fourth somite $\ldots \ldots \ldots \ldots \ldots$

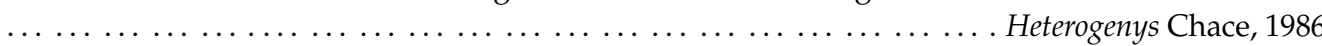

- Tooth on third abdominal somite, if present, not overreaching fourth somite $\ldots \ldots \ldots \ldots \ldots 4$

4. Carapace dorsally denticulate over nearly entire length; first abdominal somite dorsally carinate

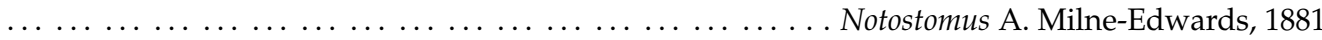

- Carapace dorsally not denticulate on posterior half; first abdominal somite smooth . . . . . . 5 5. A single continuous lateral carina on carapace (extending from near orbit to near posterior margin on carapace $\ldots \ldots \ldots \ldots \ldots \ldots \ldots \ldots \ldots \ldots \ldots \ldots \ldots \ldots \ldots \ldots \ldots \ldots$ Meningora Smith, 1882

- None or two continuous lateral carinae on carapace (one extending from near orbit, another extending from near branchiostegal spine)

. Acanthephyra A. Milne-Edwards, 1881

6. Rostrum unarmed. Meri and ischia of pereopods greatly wide and compressed ..........

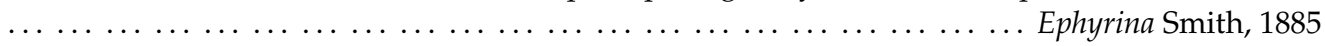

- Rostrum denticulate. Meri and ischia of pereopods not greatly wide and compressed . . . . . 7 7. Rostral teeth subuliform, spaced from each other. Cornea subequal or narrower than eyestalk

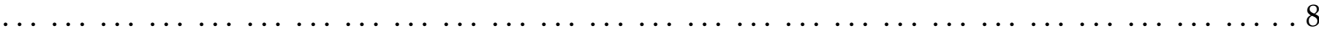

- Rostral teeth subtriangular, extending from a common crest. Cornea wider than eyestalk ... . 9

8. Dorsal subuliform teeth only on rostrum $\ldots \ldots \ldots \ldots \ldots \ldots \ldots \ldots \ldots \ldots \ldots$

Hymenodora G.O. Sars, 1877

- Dorsal subuliform teeth both on rostrum and anterior part of carapace $\ldots \ldots \ldots \ldots \ldots \ldots \ldots$

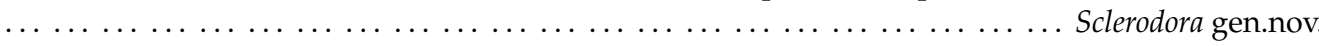
9. Carapace strongly chitinized, subtriangular in cross-section. Abdomen with sixth somite not longer than fifth, third to fourth somites with strong dorsomedial spines (at least $\frac{1}{2}$ of segment

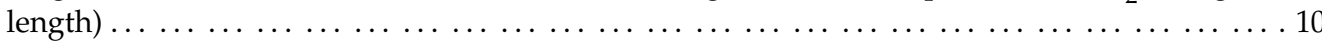
- Carapace moderately chitinized, suboval in cross-section. Abdomen with sixth somite nearly twice as long as fifth, third to fourth somites without strong dorsomedial spines . . . . . . . . .

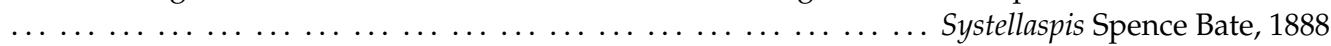
10. Second abdominal somite with strong dorsomedial spine. . . . . . . . . Janicella Chace, 1986 - Second abdominal somite without strong dorsomedial spine $\ldots \ldots \ldots \ldots \ldots \ldots \ldots \ldots$ Oplophorus H. Milne Edwards

\subsection{A New Suggested Cleaning and Grooming Mechanism}

Examination of epipods and fifth pereopods in all species of Oplophoroidea reveals a remarkable co-evolution between both characters. In this superfamily, reduction of the fourth epipod is associated with development of a chelate structure on the fifth pereopod. This structure is morphologically similar in all genera (Figure 1) and remarkably resembles grooming chelae in other carids as illustrated in [4]. When we map these synapomorphies on a phylogenetic tree (Figure 2B), we can see that a chelate structure on the fifth pereopod (linked to a lost epipod on the fourth pereopod and indicating active grooming) is a derived structure, whereas a long dactyl not forming chelate structure (linked to a full set of the epipods and passive grooming) occurs basally on the morphological tree and likely plesiomorphic as suggested by Bauer [4].

We suggest that Acanthephyridae evolved an active cleaning mechanism, which is a derived one and alternative to that described by Bauer [4,5]: posterior branchiae are groomed and cleaned by the fifth pereopods instead of the chelipeds. Convergent chelate structures suggest that the chela is especially efficient for cleaning and grooming branchiae, whichever appendage is adapted for these functions. In Oplophoridae, which are basal on the phylogenetic morphological tree, the cleaning function is carried out passively by well-developed epipods.

Our results confirm Bauer's $[4,5]$ statement that the major type of gill-cleaning method is generally a characteristic at the family level and that the active cleaning is more derived 
than the passive one. Interestingly, in Oplophoridae the last three pereopods likely take another function and act as a holding structure during mating [10], which may favor copulation in the turbulent water column [9].

Supplementary Materials: The following are available online at https:/ /www.mdpi.com/article/10 .3390/d13110536/s1, File S1: Character list, File S2: Character state, File S3: Retrieved morphological trees. Bremer support, File S4: Retrieved morphological trees. Bootstrap support, File S5: Synapomorphies, File S6: Maximum likelihood (RAxML) phylograms for each individual gene dataset, File S7: Partitioning scheme and best models selected by PartitionFinder2, File S8: Molecular BI and ML trees, File S9: Estimates of evolutionary divergence between species.

Author Contributions: A.L. analyzed the specimens morphologically; D.K. ran the genetic analyses; A.V., A.L. and D.K. wrote the paper and participated in the revisions of it. All authors have read and agreed to the published version of the manuscript.

Funding: This research was supported by RSF Project No. 18-14-00231.

Institutional Review Board Statement: Not applicable.

Data Availability Statement: Data is contained within the article and supplementary material.

Acknowledgments: We thank S.G. Kobylyansky for material from the 39th Cruise of the R/V "Professor Logatchev"; H. Braken-Grissom, Laura Corbari, J. Olesen and T. Sutton for possibility to examine specimens of Oplophoroidea.

Conflicts of Interest: None of the authors have any financial competing interests.

\section{References}

1. Dawson, M.N. Species richness, habitable volume, and species densities in freshwater, the sea, and on land. Front. Biogeogr. 2012, 4. [CrossRef]

2. Costello, M.J.; Chaudhary, C. Marine biodiversity, biogeography, deep-sea gradients, and conservation. Curr. Biol. 2017, 27, 511-527. [CrossRef] [PubMed]

3. WoRMS Editorial Board. World Register of Marine Species. 2021. Available online: http:/ /www.marinespecies.org (accessed on 4 October 2021). [CrossRef]

4. Bauer, R.T. Decapod crustacean grooming: Functional morphology, adaptive value, and phylogenetic significance. In Functional Morphology of Feeding and Grooming in Crustacea; CRC Press: Boca Raton, FL, USA, 2020.

5. Bauer, R.T. Antifouling adaptations of caridcan shrimp (Decapoda: Caridea): Gill cleaning mechanisms and grooming of brooded embryos. Zool. J. Linn. Soc. 1979, 65, 281-303. [CrossRef]

6. Bauer, R.T. Grooming behavior and morphology in the decapod Crustacea. J. Crust. Biol. 1981, 1, 153-173. [CrossRef]

7. Wong, J.M.; Pérez-Moreno, J.L.; Chan, T.Y.; Frank, T.M.; Bracken-Grissom, H.D. Phylogenetic and transcriptomic analyses reveal the evolution of bioluminescence and light detection in marine deep-sea shrimps of the family Oplophoridae (Crustacea: Decapoda). Mol. Phylogenet. Evol. 2015, 83, 278-292. [CrossRef]

8. Chace, F.A. The Caridean Shrimps (Crustacea: Decapoda) of the Albatross Philippine Expedition, 1907-1910, Part 4: Families Oplophoridae and Nematocarcinidae; Smithsonian Institution Press: Washington, DC, USA, 1986; p. 81.

9. Lunina, A.; Vereshchaka, A. The role of the male copulatory organs in the colonization of the pelagic by shrimp-like eucarids. Deep Sea Res. Part II Top. Stud. Oceanogr. 2017, 137, 327-334. [CrossRef]

10. Lunina, A.A.; Kulagin, D.N.; Vereshchaka, A.L. Oplophoridae (Decapoda: Crustacea): Phylogeny, taxonomy and evolution studied by a combination of morphological and molecular methods. Zool. J. Linn. Soc. 2019, 186, 213-232. [CrossRef]

11. Lunina, A.A.; Kulagin, D.N.; Vereshchaka, A.L. Phylogenetic revision of the shrimp genera Ephyrina, Meningodora and Notostomus (Acanthephyridae: Caridea). Zool. J. Linn. Soc. 2020, zlaa161. [CrossRef]

12. Li, C.P.; De Grave, S.; Chan, T.Y.; Lei, H.C.; Chu, K.H. Molecular systematics of caridean shrimps based on five nuclear genes: Implications for superfamily classification. Zool. Anz. 2011, 250, 270-279. [CrossRef]

13. Nixon, K. The parsimony ratchet, a new method for rapid parsimony analysis. Cladistics 1999, 15, 407-414. [CrossRef]

14. Goloboff, P.; Farris, S.; Nixon, K. TNT: Tree Analysis Using New Technology. 2000. Available online: http:/ /www.lillo.org.ar/ phylogeny/tnt (accessed on 24 October 2021).

15. Schubart, C.D.; Huber, M.G.J. Genetic comparisons of German populations of the stone crayfish, Austropotamobius torrentium (Crustacea: Astacidae). Bull. Français Pêche Piscic. 2006, 380-381, 1019-1028. [CrossRef]

16. Folmer, O.; Black, M.; Hoeh, W.; Lutz, R.; Vrijenhoek, R. DNA primers for amplification of mitochondrial cytochrome c oxidase subunit I from diverse metazoan invertebrates. Mol. Mar. Biol. Biotechnol. 1994, 3, 294-299. [PubMed]

17. Schubart, C.D. Mitochondrial DNA and decapod phylogenies: The importance of pseudogenes and primer optimization. Crustacean 2009, 18, 47-65. 
18. Schubart, C.D.; Cuesta, J.A.; Felder, D.L. Glyptograpsidae, a new brachyuran family from Central America: Larval and adult morphology, and a molecular phylogeny of the Grapsoidea. J. Crust. Biol. 2002, 22, 28-44. [CrossRef]

19. Reuschel, S.; Schubart, C.D. Phylogeny and geographic differentiation of Atlanto-Mediterranean species of the genus Xantho (Crustacea: Brachyura: Xanthidae) based on genetic and morphometric analyses. Mar. Biol. 2006, 148, 853-866. [CrossRef]

20. Apakupakul, K.; Siddall, M.E.; Burreson, E.M. Higher level relationships of leeches (Annelida: Clitellata: Euhirudinea) based on morphology and gene sequences. Mol. Phylogenetics Evol. 1999, 12, 350-359. [CrossRef]

21. Colgan, D.J.; McLauchlan, A.; Wilson, G.D.F.; Livingston, S.P.; Edgecombe, G.D.; Macaranas, J.; Gray, M.R. Histone H3 and U2 snRNA DNA sequences and arthropod molecular evolution. Aust. J. Zool. 1998, 46, 419-437. [CrossRef]

22. Edgar, R.C. MUSCLE: Multiple sequence alignment with high accuracy and high throughput. Nucleic Acids Res. 2004, 32, 1792-1797. [CrossRef] [PubMed]

23. Kumar, S.; Stecher, G.; Li, M.; Knyaz, C.; Tamura, K. MEGA X: Molecular Evolutionary Genetics Analysis across computing platforms. Mol. Biol. Evol. 2018, 35, 1547-1549. [CrossRef] [PubMed]

24. Stamatakis, A. RAxML version 8: A tool for phylogenetic analysis and post-analysis of large phylogenies. Bioinformatics 2014, 30, 1312-1313. [CrossRef]

25. Edler, D.; Klein, J.; Antonelli, A.; Silvestro, D. raxmlGUI 2.0 beta: A graphical interface and toolkit for phylogenetic analyses using RAxML. Methods Ecol. Evol. 2021, 12, 373-377. [CrossRef]

26. Ronquist, F.; Teslenko, M.; Van Der Mark, P.; Ayres, D.L.; Darling, A.; Höhna, S.; Huelsenbeck, J.P. MrBayes 3.2: Efficient Bayesian phylogenetic inference and model choice across a large model space. Syst. Biol. 2012, 61, 539-542. [CrossRef] [PubMed]

27. Lanfear, R.; Frandsen, P.B.; Wright, A.M.; Senfeld, T.; Calcott, B. PartitionFinder 2: New methods for selecting partitioned models of evolution for molecular and morphological phylogenetic analyses. Mol. Biol. Evol. 2016, 34, 772-773. [CrossRef] [PubMed]

28. Kimura, M. A simple method for estimating evolutionary rate of base substitutions through comparative studies of nucleotide sequences. J. Mol. Evol. 1980, 16, 111-120. [CrossRef] [PubMed] 